\title{
The Assessment of Interior Design Graduate Employability Skills of From Malaysia Employer Perspective
}

\author{
Ahmad Alzabadani Alrifa ${ }^{1}$, Valliappan Raju ${ }^{2}$ \\ Limkokwing University of Creative Technology, Cyberjaya, Malaysia ${ }^{1,2}$
}

\begin{abstract}
The objective of this study is to explore company perceptions of graduate student employability. This study is novel, as research focused on employability, is theoretic, remains dedicated to discovering employability of undergraduates and largely neglects to determine company perceptions of factors that increase employability of graduate. The survey measured the employers' satisfaction as well as their perspectives on the importance of attributes that are required from graduates at the workplace. This research found three concepts of employability skills which include soft skills, hard skills and personal attributes from the literature. Also, from the survey, this research found a framework which includes soft skills, hard skills and personal attribute skills which were later on merged to form the framework of employability skills. The discussions of findings were presented according to the research questions. The objective of this study is to determine the relationship between design graduates' skills (soft skills, hard skills and personal attributes) and employers' satisfaction
\end{abstract}

Keywords: Pre - Graduate - Experience, Employability, University Graduates, Hard Skills, Soft Skills, Interior Design, Malaysia

\section{INTRODUCTION}

Globalisation makes graduate recruitment to get an organisation technical. Employers believe a work force that is competitive is a key into this achievement of a firm. Although graduates are believed to own great specific skills, they still suffer from employability skills, and their job's standard affects. The company world today is extremely competitive. National surveys consistently indicate that organizations have difficulty finding employees with the ideal skills $[1,2,3]$. Research analysing the consequences of graduate instruction after graduates' transition into the work force has been studied as the 1990s. This was once the career success of graduates started initially to be implemented as a crucial index to measure the quality of education in general, and degree specifically [4]. Improving graduates' employability converted. The wants of the labor market changed due to technological advancements in addition to the globalisation with this economy. These generated doubts at the labor market, which left it unclear about what skill sets, also, were needed for faculty graduates to generate a successful transition into the work force. Recently, the government and also the researchers have led the way in researching the relationship between employability skills and additionally industry. Generally speaking, many scholars [5] discovered that equipping with acceptable employability skills make a major difference by potential recruiters also to the prosperity of participants of the work force.

Current evidence suggests that investment in growing skills is connected with gains in quality of graduates and growth has higher returns to occur when growth is followed closely by individual resource clinics [6]. Moreover, there's a wholesome relationship between graduates' quality and occupation outcome [7]. with a range of employability skills being highly appreciated in the labour market [8]. However the present employability skills supply isn't fitting requirement. Despite the total amount of Malaysian literature concerning employability skills and employment-related consequences, academic research studies focusing solely upon investigating the relationship between employability skills and employers (in overall or any field) are incredibly infrequent, and there's not any direct evidence in regards to the effect of employability skills on company satisfaction. Furthermore, the majority of the research doesn't identify employability skills and distinguish them by a dimension of skills. In Feb, whilst employability skills are promoted as identified and improving the employability of graduate's skills in an assortment of fields, for example, civil engineer [9] and many more, thus higher schooling, there has been much less emphasis on researching the connections between interior design employability skills and employers' pride.

However, some professional and investigators studies [10] have attempted to set a matchup between employability skills and employers, these driven studied by the major thing requires more rigorous empirical signs to interpret in to clinics which solve employability problems and more attention in the sphere of investigation. As a result of this, there 


\section{International Advanced Research Journal in Science, Engineering and Technology}

Vol. 6, Issue 4, April 2019

is a shortage of empirical research in this field and also the unexplored statistical relationship between employability skills and company's satisfaction pursuits that both the research workers since it seems that this relationship has a much greater affect graduates' long term growth compared to literature suggests. From the conversation above, to overcome this issue Examining the institution between graduate's employability skills on company's satisfaction, also to examine the result of work experience.

\section{A. Malaysian University}

II. LITERATURE REVIEW

Higher Education Institution that is Malaysian serves to disseminate education or knowledge, skills, exposure and experience. It intends to expand students' potential and later produce entirely incorporated graduates in terms of intellectual, spiritual, emotional as well as physiological. Once graduate, this potential human funding will likely be knowledgeable, own excellent personality, responsible and able to generate compatible family, society and state [11]. Public universities in Malaysia have increased to a total of 20 from seven in the 1990s in 2006. A total of 28 universities also have been growing until 2011. At exactly the exact same time, you will find more than 500 other associations, including university colleges, branch campuses of both overseas and local institutions, open universities and other associations with non-university status like teacher education institutes, polytechnics and community colleges [12]. Due to this growth amount of higher education associations, the entire number of graduates increased by 249,612 graduates at 2012 into 283,627 graduates at 2016 where public university graduates climbed by 121,799 to 124, 223 while private university graduates climbed from 85,669 into 97,333 at 2016 (MOHE, 2016-2012).

\section{B. Employability}

Employability is an expression that's usually utilized as a dimension by employers on graduates' marketability [15] Meanwhile, the [14] (2008) defines employability because graduate's labor market outcomes and few days jobless or possibility of jobless. Lim says that normally the graduates are having an overall total of 138 days to be jobless which can be equivalent of 4.6 weeks. This study conceptualizes employability since the capacity of the university students to be self-explanatory to become employed.

\section{Employability Skills}

Employability skills may also be called job preparation skills. Broadly speaking, employability skills are required by students to organize themselves to satisfy the requirements of many diverse jobs up on collaboration $[16,19,20]$ said that employability skills might be outlined as vital skills for procuring job, including basic skills in writing, reading, arithmetic, and believing and problem-solving skills. As stated by [21], employability skill denotes the quality and private insight that a graduate need to possess. That will be to help with the employability of their graduate and also to further help the graduate to develop into worker. A couple of researchers' states that employability skills can be really actually just a couple of achievement, understanding, and individual attitudes or qualities which indicate the patient as more competent to find the desired project and successful at career choice $[23,25,26]$ additionally agrees that attitude is equally as crucial as the hard and soft skills so as to be properly used. Broadly speaking, employability skills are such elements of skills and knowledge students will need to need to equip them to satisfy employment requirements when they've completed their research studies.

\section{Human Capital Theory}

Human capital theory originates from Shultz in 1961 and updated by Becker in 1964. The theory argues that education provides human with knowledge, skills and abilities. The more educated people are, the more they are able to perform in their jobs and thus, their productivity increase [27]. This theory is the landscape for this study.

\section{METHODOLOGY}

The researches will be a study employing a quantitative approach. The research questionnaire was developed based on previous studies and was pilot tested to twenty-six pupils of a university. The Cronbach's Alpha was calculated and the worth of more than 0.8 suggests that the things form a scale that has good internal consistency reliability. The questionnaire contains four components which are market and skills. The response scale used in this study is just five Likert scale that is 1: strongly disagree to 5: strongly agree. Employability skill in this study was analyzed according to soft skill and hard skill. Respondents were requested to evaluate the value of the skills in locating occupation.

The questionnaire has been finalized and distributed to reviewers at the beginning of their lessons. Before finishing the research questionnaire, the students are given some introduction of this research and some directions on completing the questionnaire. Each respondent was given a token of admiration on the recurrence of this questionnaire. The population of this study is university students as this study intends to measure job readiness in terms of employability skills. Therefore, three public and three private universities have been chosen for its samples. Purposive random sampling 


\section{International Advanced Research Journal in Science, Engineering and Technology}

Vol. 6, Issue 4, April 2019

method can be employed for distributing the questionnaires. Descriptive and inferential analysis were utilized to analyze the information. Descriptive analysis is conducted for the profile of the respondents and the key factors of this study. Evaluation was conducted to obtain the extent of work openness concerning employability skills between variety and sex of institutions.

\section{RESULT}

In order to estimate and validate the model, partial least squares path modelling (PLS-PM) has been implemented. This process enables the hypothesised linkages among the seven latent factors to be anticipated, as well as the extent to which they're adequately quantified by the corresponding detected indicators to be evaluated [28, 29]. PLS-PM doesn't require a very high requirement for regular distribution of the source information and works with a rather small sample size [31]. Additionally, PLS is used in national satisfaction indexes, and it is therefore an proper option for testing a research model like the one introduced here (IPQ, 1999). The applications Smart-PLS 2.0 M3 was used in this study to assess and validate this model. The measurement model will be assessed first, followed by the structural model.

Table1: Sample Characteristics of Respondents.

\begin{tabular}{|c|c|c|}
\hline & Frequency & Percentage \\
\hline \multicolumn{3}{|l|}{ Gender } \\
\hline Male & 103 & 69.1 \\
\hline Female & 46 & 30.9 \\
\hline Total & 149 & 100.0 \\
\hline \multicolumn{3}{|l|}{ COMPANY SIZE } \\
\hline Below 25 & 125 & 79.2 \\
\hline $25-200$ & 22 & 18.3 \\
\hline More than 500 & 3 & 2.5 \\
\hline Total & 149 & 100.0 \\
\hline \multicolumn{3}{|l|}{ Years of Experiences } \\
\hline Blow 5 years & 16 & 10.7 \\
\hline Between 5-10 years & 102 & 68.5 \\
\hline 10years or above & 31 & 20.8 \\
\hline Total & 149 & 100.0 \\
\hline \multicolumn{3}{|l|}{ Industry Sector } \\
\hline Architectural Practice & 43 & 28.9 \\
\hline Interior Design Practice & 9 & 6.0 \\
\hline Architectural Multi-Practices & 97 & 65.1 \\
\hline Total & 149 & 100.0 \\
\hline \multicolumn{3}{|l|}{ Position Title } \\
\hline Executive Manager & 31 & 20.8 \\
\hline Manager & 27 & 18.1 \\
\hline Assistant manager & 27 & 18.1 \\
\hline Human resource HR & 64 & 43.0 \\
\hline Total & 149 & 100.0 \\
\hline
\end{tabular}

\section{A. Measurement model}

Discriminant validity was observed over the correlation matrix of the constructs as showed in Table (1). When comparing the square roots of the AVE for each construct with the correlations between other constructs, outcome in Table (2) displays that the square root of AVE as the diagonal elements are greater than the off-diagonal correlations in rows and columns. therefore, the discriminant validity at the construct scale is confirmed. in shortly, the reliability and validity of reflective construct measures have been supported. Reliability was initially assessed for each item, and the obtained loadings were mainly above 0.7 , indicating good item reliability (Table 1). Guidelines suggest that the 


\section{International Advanced Research Journal in Science, Engineering and Technology}

Vol. 6, Issue 4, April 2019

standardised loading for each item should be higher than 0.7 [33]. However, an item reliability of 0.5 is still acceptable [34]. Regarding composite reliability, which measures the extent to which a latent variable is adequately represented by its indicators, all values exceeded the recommended 0.7 threshold [35]. The measurement model was further evaluated regarding convergent validity and discriminant validity. In this respect, [36] claim that convergent validity is demonstrated if the indicators present a t-value (bootstrap) that is significant for the corresponding latent variable; in other words, it must be higher than 1.96 (considering a 95\% confidence interval).

In our study, this result is verified for all items (Table 2). The average variance extracted (AVE) was also used to access convergent validity; according to Dillon and Goldstein (1984), it should exceed 0.5. Table (2) indicates that the AVE values range from 0.47 to 0.8 . Only one construct employability did not exceed the 0.5 threshold value. However, all its loadings exceeded the level and are statistically significant, and so it was considered to have sufficient convergent validity. To assess discriminant validity, the average variance extracted for each construct must be higher than the squared correlations between the construct and all the other constructs in the model [27] This analysis indicates adequate discriminant validity, apart from three situations regarding employability. Nevertheless, the analysis of the cross-loadings, which are another measure of discriminant validity, shows that all items' loadings are higher than all of their cross-loadings, dissipating any uncertainty as far as employability is concerned.

\section{B. Structural model}

we provide the estimated path coefficients and corresponding p-values for the structural model. This provides evidence that employability is a key antecedent of image and that image is the most important antecedent of satisfaction. As can be observed, nine of the twelve path coefficients are statistically significant at a $95 \%$ confidence level. Within each ellipse, the R2 values are presented. The latent variable satisfaction reports the greatest R2 (0.754). Loyalty also reports an R2 value superior to 0.67 , indicating the adequacy of the model and data for the issue under study. Note also the high R2 (0.525) associated with the latent variable image. The dashed grey lines represent the hypotheses involving direct effects that are rejected.

\section{Testing the research hypotheses}

The results shown in Fig. 2 allow the testing of the hypotheses that involve direct relationships between latent variables. All tests were conducted to a 95\% confidence level. Some hypotheses were rejected: H1 (p40.05), H3 (p40.10), and H7 (p40.10). To test H10, the indicators relating to non-human elements were dropped, and the model was re-estimated considering only the indicators related to human elements. This procedure produced a significant path diagram estimate of 0.2281 (po0.01), which validated H10.

Table 2: Hypothesis relationship and result

\begin{tabular}{|c|c|c|c|c|c|c|c|c|}
\hline 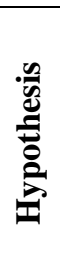 & $\begin{array}{c}\text { Exogenous variables } \rightarrow \text { Endogenous } \\
\text { Variable }\end{array}$ & $\beta^{\mathbf{a}}$ & $\stackrel{\Xi}{\rightleftarrows}$ & $\underset{\dot{0}}{\dot{0}}$ & 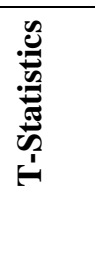 & 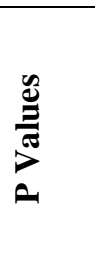 & 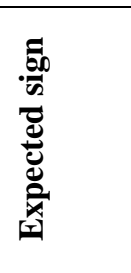 & 气ี \\
\hline H1 & $\begin{array}{l}\text { Soft skills (SS) } \rightarrow \text { Employers Satisfactions } \\
\text { (ES) }\end{array}$ & 0.304 & 0.305 & 0.090 & 3.363 & 0.001 & Positive & $\mathrm{S}$ \\
\hline $\mathrm{H} 2$ & $\begin{array}{l}\text { Hard skills (HS) } \rightarrow \text { Employers } \\
\text { Satisfactions }(\mathrm{ES})\end{array}$ & 0.231 & 0.221 & 0.094 & 2.466 & 0.014 & Positive & $\mathrm{S}$ \\
\hline H3 & $\begin{array}{l}\text { Personal attributes }(\mathrm{PA}) \rightarrow \text { Employers } \\
\text { Satisfactions }(\mathrm{ES})\end{array}$ & 0.136 & 0.142 & 0.070 & 1.927 & 0.054 & Positive & $S$ \\
\hline $\mathrm{H} 4$ & $\begin{array}{l}\text { Pre-Graduate Work Experience }(\mathrm{WX}) \rightarrow \\
\text { Employers Satisfactions }(\mathrm{ES})\end{array}$ & 0.175 & 0.186 & 0.073 & 2.393 & 0.017 & Positive & $S$ \\
\hline
\end{tabular}

\section{DISCUSSION AND CONCLUSION}

The results indicated the Interior design graduates ought to be well equipped with all the subsequent knowledge including soft skills (communication skills, problems solving skills and teamwork skills), hard skill (style skills, project management skills and computer skills) and personal attributes. On the other hand, the next knowledge such as functional training, company law, research procedures, business plan, technology issues, economics and ethics ought to be given greater emphasis for those graduates too. The findings of the study were supported by the findings from this 


\author{
Vol. 6, Issue 4, April 2019
}

former researcher [39, 40, 41] and enlarge the comprehension of this Malaysia interior design' perceptions and employers regarding interior design graduates in Malaysia. Design students should think about the qualities which are considered to be significant by design to be integrated into the planned program accordingly.

Primarily, this study offers proof that interior designer and employers perceived equally on the basic attributes that have to be considered from the program within the instructional system. Employers also suggested that interior design graduates revealed top skills in a style program system, written and oral communication skills, negotiating skills and conclusion ability. Layout graduates must also demonstrate high skills in research writing, managerial ability, presentation ability, solving-problem and critical thinking. However, employers may think that interior design graduates lack social skill. The study also discovered that employers believed that the degree of style graduates' skills had been significant, particularly in implementing analytical methods; critical thinking and can operate independently. Graduates of interior design must also reveal their capacity in handling clients, ability to apply theoretical understanding, execute technological evaluation and re-evaluation, capable of functioning in class and technology and company strategy. The findings also suggest that employers need work-ready graduates using pre-graduate function expertise. These findings also supported previous study, for example, [38, 42] which implied that employers think graduates have clear expectations of life within the company world and are usually deficient in social skills.

While combined education programs can offer an ideal car to bridge the difference between the area of work and also the area of instruction, curriculum developers have to be cautious and make sure they know the area of the job, and so the competencies required for interior design graduates. Since the focus changes from a job into employability, graduates need to realize their approach to work is equally as critical as the job itself. Additional their willingness and ability to undertake expert training and development during their working lifetime isn't just anticipated but will probably be a requirement for lifelong perform. A significant contribution that concerted interior design education programs will cause pupils' future job life will be to assist them to realize that the workplace is merely a distinct learning establishment compare to high education instruction. It's a location where the program is un-stated and also the learning outcomes uncertain but, significantly, it's a location where they need to take responsibility for identifying their learning needs and do something on it, always.

\title{
REFERENCES
}

[1]. Alves, H., and Raposo, M. (2007a). Conceptual model of student satisfaction in higher education. Total Quality Management, 18(5), 571-588.

[2]. Alves, H., and Raposo, M. (2007b). Student satisfaction index in Portuguese public higher education. The Service Industries Journal, 27(6), 795-808.

[3]. Anctil, Eric., (2008). Selling Higher Education: marketing and advertising America's Colleges and Universities: ASHE Higher Education Report, Vol. 34 (no. 2). Las Vegas: ASHE Higher Education Report Series.

[4]. Anderson, E., and Sullivan, V. (1993). The antecedents and consequences of customer satisfaction for firms. Marketing Science, 12, 125-143.

[5]. Belanger, C., Mount, J., and Wilson, M. (2010). Institutional image and retention. Tertiary Education and Management, 8(3), $217-230$.

[6]. Brown, R., and Mazzarol, T. (2009). The importance of institutional image to student satisfaction and loyalty within Higher Education. Higher Education, 58, 81-95.

[7]. Butt, B., and Rehman, K. (2010). A study examining the students satisfaction in Higher Education. Procedia Social and Behavioral Sciences, 2, 5446-5450.

[8]. Campostrini, S., and Gerzeli, S. (2007). Informative sources for the evaluation of the university education effectiveness in Italy. In L. Fabbris (Ed.), Effectiveness of university education in Italy. Employability, competences, human capital (pp. 2-9). Padua: Physica-Verlag.

[9]. Cassel, C., and Eklof, J. A. (2001). Modelling customer satisfaction and loyalty on aggregate levels: Experience from the ECSI pilot study. Total Quality Management, 12(7and8), 834-841.

[10]. Catramby, T. C., and Costa, S. R. (2004). Qualificação profissional em turismo como fator de competitividade do setor. Caderno Virtual de Turismo, 4(3), 26-34.

[11]. Chiandotto, B., Bini, M., and Bertaccini, B. (2007). Quality assessment of the university educational process: An application of the ECSI model. In L. Fabbris. (Ed.), Effectiveness of university education in Italy. Employability, competences, human capital (pp. 43-54). Padua: Physica-Verlag.

[12]. Chin, W., and Newsted, P. (1999). Structural equation modeling analysis with small samples using partial least squares. In R. Hoyle (Ed.), Statistical strategies for small sample research (pp. 307-342). Thousand Oaks, CA: Sage.

[13]. Chin, W. (1998). The partial least squares approach to structural equation modeling. In G. A. Marcoulides (Ed.), Modern methods for business research (pp. 295-336). London: Lawrence Erlbaum Associates.

[14]. 1Chitty, B. and Soutar, G. (2004). Is the European Customer Satisfaction Index Model Applicable to Tertiary Education? ANZMAC 2004 Conference Wellington (pp. 1-7). Australian and New Zealand Marketing Academy.

[15]. De Vos, A., De Hauw, S., and Van der Heijden, B. (2011). Competency development and career success: The mediating role of employability. Journal of Vocational Behavior, 79, 438-447.

[16]. Dillon, W., and Goldstein, M. (1984). Multivariate analysis. Methods and applications. New York: Wiley.

[17]. Engberg, M.E (2007). Educating the workforce for the 21 st century: a cross-disciplinary analysis of the impact of the undergraduate experience on students' development of a pluralistic orientation. Research in Higher Education, 3(48), 283-317.

[18]. Eskildsen, J., Martensen, A., Gronholdt, L., and Kristensen, K. (2000). Benchmarking student satisfaction in higher education based on the ECSI methodology. sinergie raporti di ricerca, 9, 385-402.

[19]. Fornell, C., and Larcker, D. (1981). Structural equation models with unobservable variables and measurement error: Algebra and statistics. Journal of Marketing Research, 18(3), 328-388. 


\title{
International Advanced Research Journal in Science, Engineering and Technology
}

\author{
Vol. 6, Issue 4, April 2019
}

[20]. Gedye, S., Fender, E., and Chalkley, B. (2004). Students' undergraduate expectations and post-graduation experiences of the value of a degree. Journal of Geography in Higher Education, 28(3), 381-396.

[21]. Gefen, D., and Straub, D. (2005). A practical guide to factorial validity using PLS-graph: Tutorial and annotated example. Communications of the Association for Information Systems, 16(25), 91-109.

[22]. González, M., Comesaña, L., and Brea, J. (2007). Assessing tourist behavioral intentions through perceived service quality and customer satisfaction. Journal of Business Research, 60, 153-160. Hair, J., Ringle, C., and Sarstedt, M. (2011). PLS-SEM: Indeed a silver bullet. Journal or Marketing Theory and Practice, 19(2), 139-151.

[23]. Hartman, D., and Schmidt, S. (1995). Understanding student/alumni satisfaction from a consumer's perspective. Research in Higher Education, $36(2), 197-217$

[24]. Harvey, L. (2001). Defining and measuring employability. Quality in Higher Education, 7(2), 97-109.

[25]. Harvey, L. (2010). New realities: The relationship between higher education and employment. Tertiary Education and Management, 6(1), 3-17.

[26]. Hemsley-Brown, J. (2012). 'The best education in the world': Reality, repetition or cliché? International students' reasons for choosing an English University. Studies in Higher Education, 37(8), 1005-1022.

[27]. Hennig-Thurau, T., Langer, M., and Hansen, U. (2001). Modeling and managing student loyalty: An approach based on relationship quality. Journal of Service Research, 4, 331-344.

[28]. Hillage, J., and Pollard, E. (1998). Employability: Developing a framework for policy analysis. EfEE Research Briefing, 85, 85.

[29]. Johnson, M., Gustafsson, A., Andreassen, T. W., Lervik, L., and Cha, J. (2001). The evolution and future of national customer satisfaction index models. Journal of Economic Psychology, 22, 217-245.

[30]. Kivinen, O., and Nurmi, J. (2007). Job requirements and competences: do qualifications matter? In U. Techler (Ed.), Careers of university graduates (pp. 131-142). Kassel: Springer.

[31]. Knight, P., and Yorke, M. (2003). Employability and good learning in higher education. Teaching in Higher Education, 8(1), 3-16.

[32]. Kohler, J. (2004). The bologna process and employability: The impact of employability on curricular development. A key objective of academic studies and for academic institutions. Conference Bled/Slovenia (p. 1-21). Bled/Slovenia: s.e.

[33]. Kristensen, K., Kanji, G., and Dahlgaard, J. (1992). On measurement of customer satisfaction. Total Quality Management, 3(2), $123-128$.

[34]. Kristensen, K., Martensen, A., and Gronholdt, L. (2000). Customer satisfaction measurement at post Denmark: Results of application of the european customer satisfaction index methodology. Total Quality Management, 11(7), 1007-1015.

[35]. Kristensen, K., Martensen, A., and Gronholdt, L. (1999). Measuring the impact of buying behaviour on customer satisfaction. Total Quality Management 10(4/5), 602-614.

[36]. Kurtz, D., Clow, K., Ozment, J., and Ong, B. (1997). The antecedents of consumer expectations of services: An empirical study across four industries. The Journal of Services Marketing, 11(4), 230-248.

[37]. Martensen, A., Grønholdt, L., Eskildsen, J., and Kristensen, K. (2000). Measuring student oriented quality in higher education: Application of the ECSI methodology. Sinergie Rapporti di Ricerca, 9, 371-383.

[38]. Mason, G., Williams, G., and Cranmer, S. (2009). Employability skills initiatives in higher education: What effects do they have on graduate labour market outcomes?. Education Economics, 17(1), 1-30.

[39]. Vinzi, V., Chin, W., Henseler, J., and Wang, H. (2010). Handbook of partial least squares. Concepts, methods and applications. Heidelberg: Springer. Vrontis, D.,

[40]. Thrassou, A., and Melanthiou, Y. (2007). A contemporary higher education student-choice model for developed countries. Journal of Business Research, 60, 979-989.

[41]. Webb, D., and Jagun, A. (1997). Customer care, customer satisfaction, value, loyalty and complaining behavior: validation in a UK university setting. Journal of Consumer Satisfaction, Dissatisfaction and Complaining Behavior, 10, 139-151.

[42]. Yorke, M. (2004). Employability in the undergraduate curriculum: some student perspectives. European Journal of Education, $39(4), 109-427$. Zeithaml, V. (1987). Defining and relating price, perceived quality and perceived value (Report no. 87-101). Cambridge: Marketing Science Institute. 